\title{
Visual inspection of cervix with acetic acid in early diagnosis of cin and early cervical cancer
}

\author{
Jyoti Bindal, Sanju Agrawal*
}

Department of Obstetrics and Gynecology, G.R. Medical College, Gwalior, Madhya Pradesh, India

Received: 05 June 2017

Accepted: 29 June 2017

\section{*Correspondence:}

Dr. Sanju Agrawal,

E-mail: sanjugrmc@gmail.com

Copyright: (C) the author(s), publisher and licensee Medip Academy. This is an open-access article distributed under the terms of the Creative Commons Attribution Non-Commercial License, which permits unrestricted non-commercial use, distribution, and reproduction in any medium, provided the original work is properly cited.

\begin{abstract}
Background: The cervix is the commonest site of female genital tract cancer worldwide. Cancer cervix has a long pre-invasive stage, giving an opportunity for its early detection and treatment.

Methods: The present study conducted on 400 patients in OPD and Indoor admitted patients during the period of June 2015 to Sept. 2016. Pap's smears were studied and reported according to the Bethesda classification. On next visit patient attended with cytology report and VIA, VILI was performed and then subjected to colposcopy.

Results: The mean age of our population and VIA positivity were 38.2 and 36.8 years. Majority of VIA positive cases had white discharge or pain in lower abdomen as their presenting complaints. The majority of patients who were VIA positive either had cervical ectropion or a hypertrophied cervix. 22 cases were positive on Pap smear and 66 cases were positive on VIA. Only 2 cases positive on Pap smear were missed by VIA. VIA is more sensitive than pap smear. $93.33 \%$ of cases, positive on colposcopy were detected by VIA testing. VIA is more sensitive and pap smear more specific in screening of cancer cervix sensitivity ratio of VIA with pap smear is $1.55 \%$.

Conclusions: VIA is an attractive test in low resource settings like India. It is simple, inexpensive, low technology test that requires minimal infrastructure for use. It is comparable to cytology in detecting low as well as high grade lesions in terms of sensitivity, specificity and positive predictive value.
\end{abstract}

Keywords: Cancer cervix, Colposcopy, VIA

\section{INTRODUCTION}

Cervical cancer is the second most common cancer worldwide. ${ }^{1}$

The cervix is the commonest site of female genital tract cancer worldwide. According to statistics, every year $8,000,000$ new cases of carcinoma cervix are diagnosed and about 5,000,000 people die from disease. Out of all cervical cancers cases seen in the world, $14 \%$ occur in the developed countries and about $86 \%$ occur in developing countries. Carcinoma cervix continues to be the most common genital cancer encountered in clinical practice in India. $^{2}$

Cancer cervix has a long pre-invasive stage, giving an opportunity for its early detection and treatment. Preventable but not prevented remains the reality for women in developing countries. It is preventable and also curable, provided it is diagnosed early enough. Health education programmes couples with early detection, appropriate management and availability of standard therapy have helped to reduce the morbidity and mortality up to $80 \%$ in many developed countries. ${ }^{3}$ 
Natural history of carcinoma cervix begins with minor histological atypicalities arising at the squamocolumnar junction over a period of years under preventable influencing factors, the degree of atypia increases and slowly progresses through a spectrum of changes from minor dysplasia to carcinoma in situ to frank cancer.

Cytology based screening programmes have been difficult to implement on a large scale basis, in developing countries with little impact on the incidence of cervical cancer and mortality. This has led to the development of multiple low cost, based technologies, as: Down staging Gynoscopy, visual inspection of the cervix after application of acetic acid and lugol's iodine. These would overcome the barriers posed by cytological screening. ${ }^{4}$

Visual inspection of cervix with acetic acid has several screening advantages; minimal requirement of infrastructure and equipments, immediate results, preliminary screening of high risk cases for referral and also several studies indicate that visual inspection of cervix with acetic acid has an ability, nearly equivalent to or better than that of cervical cytology to detect cervical cancer at the earliest. ${ }^{5-7}$

\section{METHODS}

The present study was carried out in Gajra Raja Medical College in the Department of Obstetrics and Gyanecology, OPD and Indoor admitted patients during the period of June 2015 to September 2016. Study included 400 cases.

All married women above the age of 18 years are included in the study. Unmarried women, women with frank invasive cancer cervix. (With visible growth on cervix), women with bleeding per vagina and pregnant women were excluded

After taking history as per proforma and consent, the women were made to lie down in modified lithotomy position. After proper positioning, she was observed for any vaginal discharge, the external genitalia and perineal region was examined.

Then a sterile vaginal speculum was introduced to observe the size and shape of the cervix. On $1 \mathrm{st} / 2$ nd visit, two smears were made after removing the excessive discharge, with the help of cotton swab. The slide was sent for cytology in the Pathology department GRMC, Medical College, Gwalior.

Pap's smears were studied and reported according to the Bethesda classification. On next visit patient attended with cytology report and VIA, VILI was performed and then subjected to colposcopy and documentation was done in proforma. 5\% Acetic acid was applied using a cotton swab, soaked in acetic acid and then cervix was carefully inspected for white lesions, particularly in the transformation zone. The results were recorded after one minute of application of acetic acid. If VIA turns out to be positive the patients were subjected to further investigations as colposcopy and biopsy and further evaluation was done by the histopathological report.

The results of visual inspection of cervix with acetic acid (VIA) were correlated with that of pap smear on the basis of sensitivity, specificity, positive predictive value.

\section{RESULTS}

The mean age of our population is 38.2 years; the mean age of VIA positivity is 36.8 years. (S.D. - 6.7).

Table 1: Distribution of VIA positive cases according to age.

\begin{tabular}{|lllll|}
\hline Age in years & Total & $\%$ & VIA positive & $\%$ \\
\hline $18-24$ & 46 & 11.5 & 2 & 3.03 \\
\hline $25-34$ & 122 & 30.5 & 24 & 36.36 \\
\hline $35-44$ & 182 & 45.5 & 26 & 39.39 \\
\hline $45-54$ & 32 & 8 & 10 & 15.15 \\
\hline$>55$ & 18 & 4.5 & 4 & 6.06 \\
\hline
\end{tabular}

Table 2: Distribution of women according to education.

\begin{tabular}{|lllll|}
\hline Education & $\begin{array}{l}\text { No. of } \\
\text { women }\end{array}$ & $\%$ & $\begin{array}{l}\text { VIA positive } \\
\text { case }\end{array}$ & $\%$ \\
\hline Illiterate & 232 & 58 & 48 & 72.72 \\
\hline Primary & 54 & 13.5 & 6 & 9.09 \\
\hline Middle & 34 & 8.5 & 4 & 6.06 \\
\hline High school & 32 & 8 & 4 & 6.06 \\
\hline $\begin{array}{l}\text { Higher } \\
\text { secondary }\end{array}$ & 32 & 8 & 2 & 3.03 \\
\hline $\begin{array}{l}\text { Graduation } \\
\text { Post }\end{array}$ & 12 & 3 & 2 & 3.03 \\
graduate & 4 & 1 & - & - \\
\hline
\end{tabular}

Table 3: Distribution of parity and VIA test results in the population.

\begin{tabular}{|lllll|}
\hline Parity & $\begin{array}{l}\text { VIA } \\
\text { positive }\end{array}$ & $\%$ & $\begin{array}{l}\text { VIA } \\
\text { negative }\end{array}$ & Total \\
\hline P0 & 2 & 3.03 & 18 & 20 \\
\hline P1 & 6 & 9.09 & 48 & 54 \\
\hline P2 & 14 & 21.21 & 116 & 130 \\
\hline P3 & 16 & 24.24 & 104 & 120 \\
\hline P4 & 16 & 24.24 & 28 & 44 \\
\hline P5 & 8 & 12.12 & 14 & 22 \\
\hline P6 & 4 & 6.06 & 6 & 10 \\
\hline
\end{tabular}

The illiterate population shows more VIA positivity. It is evident that, $58 \%$ of the women in the study group were illiterate. Such women belong to the low socio economic group and are unaware of the primary health care services. In present study majority of VIA positive cases $(70.7 \%)$ were illiterate. 
Table 3 shows that VIA positive cases were common in women who were multiparous or women with two children. High parity has high percentage of VIA positive cases.

Table 4: Distribution of cases according to presenting complaints and correlation with VIA.

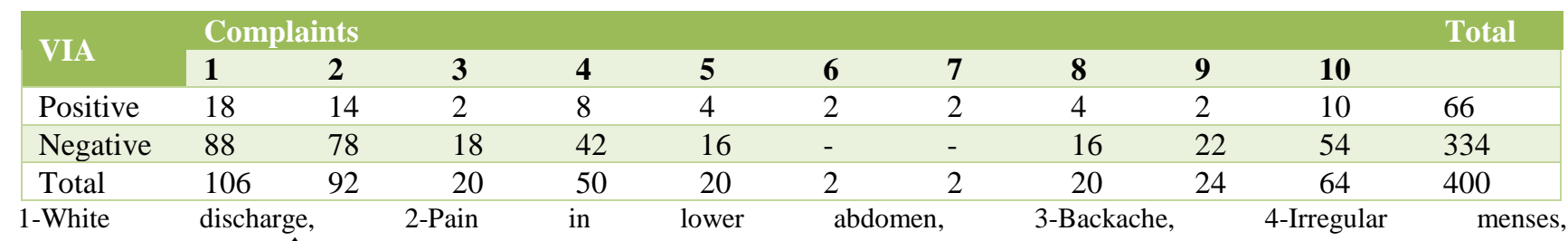

5-Urinary complaints ( $\uparrow$ Frequency of micturition, burning micturition), 6-Blood mixed discharge, 7-Post menopausal bleeding, 8Itching in private parts, 9-For check up. (asymptomatic), 10-Others (Secondary infertility, something coming out P/V, dysmenorrhea, amenorrhea etc.)

Table 5: Distribution of cases according to per speculum examination and correlation with VIA.

\begin{tabular}{|llllllllll|l|}
\hline VIA & Per speculum examination & $\mathbf{3}$ & $\mathbf{4}$ & $\mathbf{5}$ & $\mathbf{6}$ & $\mathbf{7}$ & $\mathbf{8}$ & Total \\
\hline Positive & $\mathbf{2}$ & 30 & 18 & 2 & 4 & 4 & 2 & 2 & 66 \\
\hline Negative & 152 & 92 & 50 & 4 & - & - & 18 & 18 & 334 \\
\hline Total & 156 & 122 & 68 & 6 & 4 & 4 & 20 & 20 & 400 & \\
\hline
\end{tabular}

1-Cervix vagina healthy, 2-Cervical ectropion, 3-Cervix hypertrophied, 4-Cervical growth/polyp, 5- Cervix flushed with vagina, 6Cervix atrophied, 7-Curdy white discharge, 8-Others

Majority of VIA positive cases had white discharge or pain in lower abdomen as their presenting complaints.

Table 6: Comparison and correlation of VIA with pap smear.

\begin{tabular}{|llll|}
\hline Pap smear & VIA & & \\
& Positive & Negative & Total \\
\hline Positive & 20 & 2 & 22 \\
\hline Negative & 46 & 332 & 378 \\
\hline Total & 66 & 334 & 400 \\
\hline
\end{tabular}

Table 5 presents that the majority of patients who were VIA positive either had cervical ectropion or a hypertrophied cervix.
The Table 6 shows that 22 cases were positive on Pap smear and 66 cases were positive on VIA. Only 2 cases positive on Pap smear were missed by VIA. Thus, VIA is more sensitive then pap smear. The difference between the two tests is statistically significant.

Colposcopy was performed on 80 cases out of which 66 were VIA positive and 14 cases were those of abnormal or unhealthy cervix, 29 cases had positive findings on colposcopy, 27 had VIA positive, 2 had inconclusive VIA.

93.33\% of cases, positive on colposcopy were detected by VIA testing.

Table 7: Correlation of VIA reporting with Colposcopy findings.

\begin{tabular}{|lllllll|}
\hline VIA & Colposcopy & & & & & \\
WNL & CIN I & CIN II & CIN III & Invasive cancer & Total \\
\hline Positive & 39 & 22 & 2 & 2 & 1 & 66 \\
\hline Negative & 62 & - & - & - & - & 62 \\
\hline Inconclusive & - & 2 & - & - & - & 2 \\
\hline
\end{tabular}

14 biopsy proven cases were detected by VIA and the 2 which were not detected had an inconclusive VIA test. Comparing the results of VIA and Pap smear, the sensitivity of VIA is more than pap smear. Hence it is more accurate for screening out, the true positive cases. The specificity is comparable to Pap smear where as the 
positive predictive value of pap smear is greater than VIA. The negative predictive value for VIA is $99.40 \% \mathrm{Vs}$ $98.15 \%$ for Pap smear.
VIA is more sensitive and pap smear more specific in screening of cancer cervix sensitivity ratio of VIA with pap smear is $1.55 \%$.

Table 8: Correlation of VIA and histopathology report (biopsy).

\begin{tabular}{|c|c|c|c|c|}
\hline \multirow{2}{*}{ HPR } & \multicolumn{3}{|l|}{ VIA } & \multirow[t]{2}{*}{ Total } \\
\hline & Positive & Negative & Inconclusive & \\
\hline Chronic cervicitis with atypical cells & 2 & - & - & 2 \\
\hline Mild dysplasia & 5 & - & 2 & 7 \\
\hline Moderate dysplasia & 4 & - & - & 4 \\
\hline Severe dysplasia & 2 & - & - & 2 \\
\hline Invasive cancer & 1 & - & - & 1 \\
\hline Total & 14 & & 2 & 16 \\
\hline
\end{tabular}

Table 9: Comparison of VIA with cytology according to sensitivity, specificity and positive predictive value.

\begin{tabular}{|lllll|}
\hline Test & Sensitivity & Specificity & Positive predictive & Negative predictive \\
\hline VIA & $87.5 \%$ & $56.84 \%$ & $21.21 \%$ & $99.40 \%$ \\
\hline Pap smear & $56.25 \%$ & $96.61 \%$ & $40.90 \%$ & $93.15 \%$ \\
\hline
\end{tabular}

\section{DISCUSSION}

In present study, mean age of population was 38.2 years correlating with the study of Saleh HS et al (mean age 35.1 years $)^{8}$

In present study, $75.5 \%$ population were illiterate correlating with the study of Saleh HS et al $(60 \%){ }^{8}$

The main complaints in this study were white discharge and pain in lower abdomen. Saleh HS et al found in their study chief complaints were white discharge in $61.5 \%$ and lower abdominal pain $(14 \%){ }^{8}$

In current study, on per speculum examination cervical ectropion and hypertrophy of cervix were main abnormalities of cervix correlation with study done by Saleh HS et al. ${ }^{8}$

983.3\% of cases positive on colposcocy were detected by VIA testing in our study. Study done by Saleh HS et al showed sensitivity of VIA $91.3 \%$ which is correlating with our study. ${ }^{8}$

In present study, positive predictive value of VIA is less than pap's smear $(21.21 \%, 40.90 \%)$ while negative predictive value of these tests were comparable $(99.4 \%$, $93.15 \%)$. Similar results were found in study done by Saleh HS et al (Positive predictive value - $40.11 \%$, $75.12 \%$ and negative predictive value - $98.05 \%$, $97.09 \%) .{ }^{8}$ Sensitivity and specificity of VIA in our study was $87.5 \%$ and $56.8 \%$. Similar results were found in study done by Goel A et al (sensitivity - $96 \%$ and specificity - 36\%) and Cronje et al (sensitivity - 79\% and specificity - 49\%). ${ }^{9,10}$

\section{CONCLUSION}

VIA is an attractive test in low resource settings like India. It is simple, inexpensive, low technology test that requires minimal infrastructure for use. It is comparable to cytology in detecting low as well as high grade lesions in terms of sensitivity, specificity and positive predictive value. It is a real-time test in the sense that the results are available immediately, making it possible to institute further diagnostic investigations for test positive women, as well as plan and offer treatment during the same visit.

\section{Funding: No funding sources \\ Conflict of interest: None declared \\ Ethical approval: Not required}

\section{REFERENCES}

1. Schiffman MH, Brinton LA. The epidemiology of cervical carcinogenesis. Cancer. 1995;76(S10):1888901.

2. Seung KIM. Role of colposcopy and cervicography in screening and management of precancerous lesions of uterine cervix. J Obstet Gynecol India. 2000;50:139-144.

3. Hakama M, Miller AB, Day NE. Screening for cancer of uterine cervix. International agency for research on cancer of uterine cervix. International agency for research on cancer, Lyon 1986 IARC scientific publication no. 76 . 
4. Lunt R. Worldwide early detection of cervical cancer. Obstet Gynaecol. 1984;63:708-13.

5. Sankaranarayanan R, Pisani P. Prevention measures in the third world: are they practical? In Franco E, Monsonega J.(eds) New developments in cervical cancer screening and prevention. Oxford Blackwell. Science. 1997;70:83.

6. Gaffikin L, Bluementhal PD, Davis C, Birchin SJG (eds). Alternatives for cervical cancer screening and treatment in low resource settings: workshop proceedings: Baltimore: JHPIEGO;1997.

7. Stensword J, Eddy D, Luthra U, Stanley K. Plotting a new course for cervical cancer screening in developing countries. World Health Forum 1987;8:42-5.

8. Saleh HS, El Hameid AAA, Mowafy HE, Sherif HE, Abdelsalam WA.) Visual inspection of the cervix with (acetic acid or Lugol's iodine) for cervical cancer screening. Cervical Cancer. 2016;1(1):111.

9. Goel A, Gandhi G, Batra S, Bhambhani S, Zutshi V. Visual inspectino of the cervix with acetic acid for cervical intraepithelial lesions. Int J Gynaecol Obstet. 2005;88:25-30.

10. Chronje HS, Parham GP, Cooreman BF, de Beer A, Divall P, Bam RH. A comparison of four screening methods for cervical neoplasia in a developing country. Am J Obstet Gynecol. 2003;188:395-400.

Cite this article as: Bindal J, Agrawal S. Visual inspection of cervix with acetic acid in early diagnosis of cin and early cervical cancer. Int J Reprod Contracept Obstet Gynecol 2017;6:3564-8. 